\title{
Contrasting Patterns of Colonization with Verticillium longisporum in Winter- and Spring-Type Oilseed Rape (Brassica napus) in the Field and Greenhouse and the Role of Soil Temperature
}

\author{
Xiaorong Zheng, Annette Pfordt, Laxman Khatri, Alice Bisola Eseola, Antonia Wilch, Birger Koopmann, \\ and Andreas von Tiedemann ${ }^{\dagger}$ \\ Department of Crop Sciences, Section of Plant Pathology and Crop Protection, Georg August University, Göttingen, Germany
}

\begin{abstract}
Oilseed rape, an important source of vegetable plant oil, is threatened by Verticillium longisporum, a soil-borne vascular fungal pathogen so far occurring in oilseed rape growing regions in Europe and Canada. Despite intensive research into $V$. longisporum in the last decades in controlled conditions, basic knowledge is still lacking about the time course of infection, temporal pattern of colonization, and disease development on field-grown plants. In this study, colonization of roots, stem bases, and stems with $V$. longisporum was followed by real-time PCR from the seedling until mature plant stages in 2-year field experiments with microsclerotia-infested plots and either spring-type or autumn-sown (winter-type) oilseed rape cultivars. The temporal pattern of plant colonization differed between greenhouse and field-grown oilseed rape and between spring- and winter-type plants in the field. Within 28 to 35 days, a continuous systemic colonization with $V$. longisporum was detected in roots and shoots of young plants in the greenhouse associated with significant stunting. In contrast, real-time PCR analysis of $V$. longisporum in field-grown winter oilseed rape plants displayed a strongly discontin-

colonization with the pathogen required 6 months in winter oilseed rape and 1 month in spring oilseed rape from the time of initial root infection. The different patterns of stem colonization were related to soil temperature. Average soil temperatures in 5-cm depth during 7 days before sampling time points from 2 years of field experiments displayed a significant relationship with fungal colonization in the root. A climate chamber inoculation trial with soil temperature levels that varied from 6 to $18^{\circ} \mathrm{C}$ revealed a threshold temperature of $>12^{\circ} \mathrm{C}$ in the soil to enable root invasion. This soil condition is reached in winter-type oilseed rape in the field in Germany either until the eight-leaf stage in early autumn or after pod stage in spring, whereas in spring-sown oilseed rape early root infection is delayed owing to the cool conditions during juvenile growth stages. The delay of stem colonization in field-grown oilseed rape may explain the lack of stunting as observed in the greenhouse and the previously reported inconsistent effects of $V$. longisporum on yield levels and seed quality, which were confirmed in this study.
\end{abstract} uous colonization pattern with low fungal growth in roots during juvenile growth stages until flowering, whereas in spring oilseed rape, no root colonization was observed until early flowering stages. Hence, stem

Keywords: oilseed rape, vascular disease, Verticillium longisporum, systemic colonization, soil temperature, real-time PCR, pathogen detection

Oilseed rape (Brassica napus L.) is the second most important crop for oilseed production in the world, after soybean (U.S. Department of Agriculture 2018). Owing to the multiple uses as edible vegetable oil, animal feed, and biofuel, a strong rise in the production of oilseed rape worldwide has been witnessed in the last 40 years (Friedt and Snowdon 2009; Zając et al. 2016), provoking the increased incidence of soil-borne diseases. Verticillium longisporum was first described on oilseed rape in southern Sweden in 1969 (Kroeker 1970) and since then has been established as a constraint to oilseed rape production in Europe and more recently in Canada, causing Verticillium stem striping in winter- and spring-type oilseed rape (Depotter et al. 2016; Karapapa et al. 1997; Zeise and von Tiedemann 2002). This soil-borne vascular fungal pathogen survives with melanized dormant microsclerotia in the soil for several years and may cause significant yield losses by induction of premature ripening (Dunker et al. 2008; Gladders et al. 2013). Evidence from previous studies suggests that $V$. longisporum undergoes a hemibiotrophic life cycle on its main host, oilseed rape (Depotter et al. 2016; Ralhan et al. 2012). Hyphae germinated from microsclerotia in infested soil colonize the surface of the fine roots close to the tips and directly penetrate through the rhizodermis into the root cortex, where they grow intra- and intercellularly until reaching and invading the vascular

${ }^{\dagger}$ Corresponding author: A. von Tiedemann; atiedem@gwdg.de

The author(s) declare no conflict of interest.

Accepted for publication 2 April 2019.

() 2019 The American Phytopathological Society system, to which the pathogen is restricted for an extended time span associated with a lack of disease symptoms until plant maturity (Eynck et al. 2007). Owing to its strict limitation to single vessels, even at high inoculum levels in a susceptible interaction, $V$. longisporum typically does not occupy the entire vascular system, which may explain the absence of wilting symptoms owing to $V$. longisporum infection (Eynck et al. 2007; Lopisso et al. 2017b). The first visible symptoms in the field consist of a brown striping on stems only about 4 weeks before harvest. This indicates the start of the saprotrophic stage, in which the fungus escapes from the vessels and colonizes mature stem parenchyma to form microsclerotia beneath the stem epidermis and in the stem pith (Knüfer et al. 2017). At harvest time, microsclerotia from infected plant tissues are released into the soil, where they are estimated to remain viable for more than 10 years (Depotter et al. 2016; Heale and Karapapa 1999). Until today, effective fungicide control is lacking, making this a disease to be controlled by nonchemical means such as crop rotation with nonhost crops, delayed sowing time, application of biological control agents, or use of resistant cultivars (Rygulla et al. 2008; Tyvaert et al. 2014).

There is a strong contrast in disease phenotype development between $B$. napus plants infected in the field when growing in soil amended with microsclerotia of $V$. longisporum or plants inoculated in the greenhouse by root dipping in conidial suspension. In controlled conditions, initial penetration of $V$. longisporum into the roots is usually observed within $60 \mathrm{~h}$ postinoculation without any visible symptoms in the root tissue. Three weeks after inoculation, $V$. longisporum is detectable in individual xylem vessels in the shoots of greenhouse-grown plants. Although the stem base (initial hypocotyl) has been identified as the critical root-shoot interface tissue where partial resistance to $V$. longisporum is expressed in a resistant interaction with $B$. napus, greenhouse-inoculated susceptible plants 
display a continuous linear colonization from the roots into the shoots within 4 weeks. As a result, typical disease symptoms such as halfsided yellowing of leaves and stunted growth may be observed starting at 21 days postinoculation (dpi) (Eynck et al. 2007). Such symptoms have been rarely (leaf yellowing) or never (stunting) observed in diseased field plants.

The strong differences in disease development and types of symptoms in the greenhouse and field prompted studies to reveal the potential causes. Previous studies reported the time course of colonization and disease development of $V$. longisporum in B. napus only in controlled environments (Eynck et al. 2009a; Zhou et al. 2006); however, studies are lacking so far describing the temporal pattern of infection of roots and colonization of plants in the field. This also applies to the impact of winter- and spring-type oilseed rape, which differ in their growth seasons (autumn versus spring sown) and their requirement of vernalization for flowering, which is lacking in the spring type. In addition, previous studies have estimated large variations in the overall yield losses potentially caused by $V$. longisporum, ranging from 10 to 50\% (Dunker et al. 2008). In a recent study, yield losses were insignificant or inconsistently related to visual disease symptoms, implying yet other disease parameters governing the damage potential of $V$. longisporum (Depotter et al. 2019). In greenhouse experiments, the amount of fungal DNA in plants correlated with disease severity (Eynck et al. 2009a; Lopisso et al. 2017a). Because infection of oilseed rape with $V$. longisporum in the field remains symptomless for most of the plant life span, fungal DNA content in stems at growth stage (GS) 80 has provided a suitable parameter to discriminate oilseed rape lines for resistance (Knüfer et al. 2017). Therefore, the temporal pattern of internal colonization during the growing season appears a more relevant parameter to estimate the damage potential than visible disease symptoms.

The present study was conducted (i) to elucidate the temporal patterns of colonization and development of $V$. longisporum in fieldgrown winter and spring oilseed rape from seedling to maturity stages, (ii) to identify causal factors determining the different temporal patterns of disease development in field- and climate-chamber-grown oilseed rape, (iii) to determine how colonization patterns differed between resistant and susceptible cultivars grown in the field, and (iv) to explain the variable levels of yield losses.

\section{Materials and Methods}

Plant materials. In the season 2015-16, two winter oilseed rape genotypes, B. napus L. cv. Falcon (Norddeutsche Pflanzenzucht Hans-Georg Lembke KG, NPZ, Hohenlieth, Germany) and SEM 05-500256 (SEM; breeding line) (Syngenta, Germany), and two spring oilseed rape genotypes, B. napus L. cv. Visum and OP-DLE 7 (NPZ), were used. Falcon and SEM differ in response to $V$. longisporum, the earlier being highly susceptible and the latter exhibiting quantitative resistance (Eynck et al. 2009a). Visum and OP-DLE 7 are spring oilseed rape varieties that exhibit only slight differences in response to $V$. longisporum, with the latter having been slightly less susceptible in previous greenhouse tests (data not shown). In the season 2016-17, three commercial winter oilseed rape genotypes, cv. Mentor (Norddeutsche Pflanzenzucht Hans-Georg Lembke KG), Aristoteles (Limagrain AG, Edemissen, Germany), and SY Saveo (Syngenta) were grown. Seeds were pretreated with tetramethylthiuram disulfide $(5.71 \mathrm{ml} / \mathrm{kg}$ of seeds) as a seed coating to exclude damping-off pathogens, according to the general agricultural practice. Plant growth stages were assessed following the identification key described by Weber and Bleiholder (1990) and Lancashire et al. (1991).

Conditions and design of field experiments. Two experiments with winter oilseed rape (seasons 2015-16 and 2016-17) and one with spring oilseed rape (2016) were conducted on an experimental field site near Göttingen, Lower Saxony, Germany (51 $33^{\prime} 56.9^{\prime \prime} \mathrm{N}$, $\left.9^{\circ} 55^{\prime} 9.0^{\prime \prime} \mathrm{E}\right)$. This site was selected owing to its virgin soil as regards oilseed rape cultivation.

Plots $(3 \times 16 \mathrm{~m})$ were arranged in a completely randomized block design with four replications in both the winter and spring oilseed rape experimental fields, with each plot consisting of two subplots for sampling and yield analysis. Seeding rates were 60 seeds $/ \mathrm{m}^{2}$ for winter oilseed rape, sown on 27 August 2015 and on 23 August 2016, and 100 seeds $/ \mathrm{m}^{2}$ for spring oilseed rape, sown on 7 April 2016.

In winter oilseed rape in $2015-16$, fertilizers $(205.3 \mathrm{~kg} / \mathrm{ha}$ of nitrogen, $40 \mathrm{~kg} / \mathrm{ha}$ of sulfate), herbicides (2.5 liter/ha of Butisan Gold), insecticides ( 0.2 liter/ha of Trebon), molluscicides ( $4 \mathrm{~kg} / \mathrm{ha}$ of Patrol Meta Pads), and growth regulators ( 0.7 liter/ha of Caramba) were applied according to local agricultural practice. Similarly, in spring oilseed rape in 2016 , fertilizers $(172.9 \mathrm{~kg} / \mathrm{ha}$ of nitrogen, $40 \mathrm{~kg} / \mathrm{ha}$ of sulfate), herbicides ( 2.5 liter/ha of Butisan Top), insecticides ( 0.75 liter/ha of Karate Zeon, 0.2 liter/ha of Trebon, 0.17 liter/ha of Avaunt, 0.3 liter/ha of Biscaya), fungicides ( 0.5 liter/ha of Cantus Gold), molluscicides (4 kg/ha of Arinex, $4 \mathrm{~kg} / \mathrm{ha}$ of Mollustop), and a growth regulator ( 0.7 liter/ha of Moddus) were applied. In the season 2016-17, fertilizers (221.8 kg/ha of nitrogen, $48 \mathrm{~kg} / \mathrm{ha}$ of sulfate), herbicides (2.5 liter/ha of Butisan Gold, 0.8 liter/ha of Targa Super), insecticides (0.1 liter/ha of Fastac SC Super Contact, 0.075 liter/ha of Decis Forte, 0.2 liter/ha of Trebon, 0.17 liter/ha of Avaunt), molluscicides (6 kg/ha of Patrol Meta Pads), and growth regulators (1.4 liter/ha of Moddus, 0.7 liter/ha of CCC 720) were applied.

Fungal inoculum and field inoculation. Stubbles of oilseed rape heavily infested with microsclerotia of $V$. longisporum were collected in autumn 2015 from an experimental field in Fehmarn, Northern Germany. The milled dry powder of stubbles (Kompost-Meister 2400 , Cramer, Leer, Germany) was homogeneously spread on the soil surface by hand at a rate of $15 \mathrm{~g} / \mathrm{m}^{2}$ (VL1) or $30 \mathrm{~g} / \mathrm{m}^{2}$ (VL2) shortly before sowing and incorporated into the upper soil layer using a rototiller.

Microsclerotia inoculum and climate chamber inoculation. Microsclerotia of $V$. longisporum isolate VL43 (Zeise and von Tiedemann 2002) obtained from a diseased B. napus plant were used for inoculation. In brief, microsclerotia production was started with a conidial suspension previously stored in $25 \%$ glycerol at $-80^{\circ} \mathrm{C}$ and used to initiate fresh cultures on potato dextrose agar (PDA) at $22^{\circ} \mathrm{C}$ for 14 days. Several agar plugs overgrown with mycelium from these cultures were added to an autoclaved spawn bag (PP75/BEU6/ X32-57, SacO2, Deinze, Belgium) containing a sand/flour mixture ( $840 \mathrm{~g}$ of quartz sand and $60 \mathrm{~g}$ of rye flour) and incubated at room temperature for 4 weeks in darkness. After being separated on a $100-\mu \mathrm{m}$-mesh sieve, $20 \mathrm{~g}$ of microsclerotia were mixed with 50 liters of compost/soil/sand mixture $(3: 1: 1)$. Two seeds were sown per pot $(7 \times 7 \times 8 \mathrm{~cm})$ filled with $250 \mathrm{ml}$ of the infested soil mixture. An equal amount of soil without microsclerotia was used for control plants.

Conditions and design of the climate chamber experiment. A pot experiment was installed in a completely randomized design in a climate chamber (Rumed Typ 1401S, Rubarth Apparate GmbH, Hannover, Germany) with 12-h day length provided by four ceramic/metal halide lamps (Iwasaki Electric Co., Tokyo, Japan) with 107 to $153 \mu \mathrm{mol} \cdot \mathrm{m}^{-2} \cdot \mathrm{s}^{-1}$ light intensity. The experiment included three factors: (i) genotype (Visum and Falcon), (ii) disease (noninoculated and $V$. longisporum inoculated), and (iii) temperature $\left(6,9,12,15\right.$, and $\left.18^{\circ} \mathrm{C}\right)$. Treatments were arranged in a randomized pattern with four biological replicates each composed of two plants grown in the same pot. Samples were collected at 21, 28, 35, 42, and 49 dpi.

Measurement of soil temperature. Four pT100 soil temperature sensors (Steffen Messtechnik, Dorsten, Germany) placed at 5-cm soil depth in a representative measurement plot on a field testing site near Göttingen, Lower Saxony, Germany (51 $33^{\prime} 28.3^{\prime \prime}$ N, 9 ${ }^{\circ} 57^{\prime} 6.4^{\prime \prime}$ E; Siebold and von Tiedemann 2013), were continuously operated in close vicinity to the field experimental sites. Means of readings recorded at 10-min intervals were used to calculate daily mean soil temperature.

Quantification of DNA of $V$. longisporum in different plant tissues. For the field experiments, five plants per plot were harvested at six time points and separated into three parts: root, stem base, and stem. Samples were lyophilized, and $50 \mathrm{mg}$ of dry ground plant material was used for DNA extraction. In the climate chamber experiment, fresh plant samples were ground with liquid nitrogen to a 
fine powder, and $50 \mathrm{mg}$ of ground plant material was used for extraction.

Total DNA was extracted from ground plant samples using the cetyltrimethylammonium bromide (CTAB) method (Brandfass and Karlovsky 2008). Ground plant samples were homogenized in $1 \mathrm{ml}$ of CTAB consisting of $2 \mu \mathrm{l}$ of $\beta$-mercaptoethanol and $1 \mu \mathrm{l}$ of proteinase $\mathrm{K}$. After sonication for $5 \mathrm{~s}$, the mixture was incubated for $10 \mathrm{~min}$ at $42^{\circ} \mathrm{C}$ and subsequently for $10 \mathrm{~min}$ at $65^{\circ} \mathrm{C}$. To get rid of RNA contamination, $1.5 \mu$ l of RNase was added and incubated for $15 \mathrm{~min}$ at $37^{\circ} \mathrm{C}$. For isolation of DNA from the mixture, $800 \mu \mathrm{l}$ of chloroform/isoamyl alcohol (24:1) was added and incubated on ice for $10 \mathrm{~min}$. After centrifugation at $16,099 \times g$ for $10 \mathrm{~min}$, the supernatant was mixed in $193.6 \mu \mathrm{l}$ of $30 \%$ polyethylene glycol and $100 \mu \mathrm{l}$ of $5 \mathrm{M} \mathrm{NaCl}$ for precipitation. The pellet, after centrifugation for 5 min at maximal speed, was washed with $70 \%$ ethanol. The washed pellet was dried in a centrifugal concentrator for $10 \mathrm{~min}$ at $30^{\circ} \mathrm{C}$ and dissolved overnight in $200 \mu \mathrm{l}$ of Tris/EDTA buffer at $4^{\circ} \mathrm{C}$.

The quality of extracted total DNA was tested by staining with ethidium bromide and run on 1\% agarose gel electrophoresis. For the amplification and quantification of $V$. longisporum DNA, a CFX384 real-time PCR detection system (Bio-Rad Laboratories, Hercules, CA) was used. A species-specific primer pair for $\beta$-tubulin (forward, 5'-GCAAAACCCTACCGGGTTATG-3'; reverse, 5'AGATATCCATCGGACTGTTCGTA-3') was applied (Debode et al. 2011). The amplification mix consisted of $5 \mu$ l of premix (qPCRBIO SyGreen Mix Lo-ROX, Nippon Genetics Europe, Dueren, Germany), $0.4 \mu \mathrm{M}$ of each primer, and $1 \mu \mathrm{l}$ of template DNA and filled up to a total volume of $10 \mu \mathrm{l}$ with sterilized double-distilled water. The PCR program included a 3-min initial denaturation step, followed by 40 cycles each consisting of denaturation $\left(5 \mathrm{~s}\right.$ at $\left.95^{\circ} \mathrm{C}\right)$, annealing $\left(15 \mathrm{~s}\right.$ at $\left.68^{\circ} \mathrm{C}\right)$, and subsequent extension $\left(15 \mathrm{~s}\right.$ at $\left.72^{\circ} \mathrm{C}\right)$. Fluorescence was detected after each elongation step, and the program was completed with a final elongation step of 2 min at $72^{\circ} \mathrm{C}$. Melting curve analysis was performed at $95^{\circ} \mathrm{C}$ for $10 \mathrm{~s}$, followed by a $55^{\circ} \mathrm{C}$ step for $10 \mathrm{~s}$, and subsequent measurements within a range of 65 to $95^{\circ} \mathrm{C}$ with $0.5^{\circ} \mathrm{C}$ temperature increments every $5 \mathrm{~s}$. PCR for all treatment samples was performed with four biological and three technical replicates, and data were analyzed using CFX Manager Software (Bio-Rad Laboratories).

Assessment of disease severity. A postharvest assessment of disease severity was conducted on the stubbles from field-infected plants. From each field plot, 50 stubbles of winter oilseed rape in season 2015-16 and 25 stubbles of spring oilseed rape in season 2015-16 and winter oilseed rape in season 2016-17 were randomly collected 3 weeks after harvest for the phenotypic disease assessment. Disease incidence was assessed as the proportion of diseased plants to the total number of assessed plants. Disease severity was scored by visual and microscopic observation of the presence and amount of microsclerotia in subepidermal and pith tissue on and in stems and roots using an assessment key (Knüfer et al. 2017) with four severity classes as indicated in Table 1 .

Disease development on oilseed rape plants inoculated and grown in the climate chamber was assessed with a key ranging from 1 to 9 as described previously (Eynck et al. 2009b). Net disease severity was calculated as follows:

$$
\begin{aligned}
& \text { Net disease severity }=\text { disease }^{\text {severity }}(\mathrm{VL}) \\
&- \text { mean of disease severity } \\
&(\text { Mock }) .
\end{aligned}
$$

Table 1. Assessment key for scoring disease severity of Verticillium longisporum on oilseed rape stubbles (Knüfer et al. 2017)

\begin{tabular}{ll}
\hline Score & Description \\
\hline 1 & Healthy tissue: no microsclerotia visible in tissue \\
2 & Slight infection: low abundance of microsclerotia \\
3 & Advanced infection: high abundance of microsclerotia \\
4 & Severe infection: tissue heavily infested with \\
& microsclerotia, epidermis is peeling off from the stubble \\
\hline
\end{tabular}

Measurement of seed quantity and yield. Harvested seeds were purified to remove impurities using a sample cleaner (Model MLN, Pfeuffer, Kitzingen, Germany) with a two-sieve set $(\varnothing 3.0 \mathrm{~mm}$, $1.0 \times 20 \mathrm{~mm}$ for winter oilseed rape, $\varnothing 2.8 \mathrm{~mm}, 1.0 \times 20 \mathrm{~mm}$ for spring oilseed rape). Fresh and air-dried weights were recorded after cleaning. Seed yield was determined in decitons (dt) per hectare at a standard water content of $9 \%$. Random samples taken from each plot were used for quality analysis. Protein, oil, and glucosinolates were determined in the Plant Breeding Division, Georg August University Göttingen, using near-infrared reflectance spectroscopy. Owing to strong damage caused by the pollen beetle (Meligethes aeneus) during flowering and extreme weather conditions leading to lodging at maturity, no valid yield analysis was possible in spring oilseed rape.

Statistical analysis. The experimental field data were analyzed as a completely randomized design with four replications using Statistica 13.3. Before testing for statistical significance, a probability plot with the Shapiro-Wilk test was used to test for normal distribution. The data were analyzed with factorial ANOVA. A multiple comparison was analyzed by Fisher LSD test. Nonnormally distributed data were analyzed by Kruskal-Wallis test (two-tailed). The experimental results are presented as means \pm standard errors at a $5 \%$ level of significance.

\section{Results}

Colonization and development of $V$. longisporum in fieldgrown winter oilseed rape. Samples from roots, stem bases, and stems collected at GS 14 (four-leaf stage), 18 (eight-leaf stage), 32 (two visibly extended internodes), 55 (main inflorescence visible but still closed), 65 (full flowering), and 80 (beginning of ripening) were analyzed with real-time PCR for colonization and growth of $V$. longisporum in oilseed rape plants. No visible symptoms of stem striping were observed on any of these collected samples. At GS 14, DNA of $V$. longisporum was only detectable at low levels in the root tissue of all cultivars in both seasons (Fig. 1). In season 2015-16, 100 times higher amounts of $V$. longisporum DNA were recorded in the susceptible Falcon $(0.322 \mathrm{ng} / \mathrm{g}$ dry weight) compared with the resistant cultivar SEM (0.003 ng/g dry weight), whereas in season 2016-17, no differences were found between cultivars. Compared with season 2015-16, the mean of soil temperature from sowing to GS 14 was significantly higher in season 2016-17 (Fig. 2, 16 versus $\left.21^{\circ} \mathrm{C}, P<0.0001\right)$. DNA of $V$. longisporum was found in stem bases of both cultivars at GS 14 in season 2016-17 (Fig. 1A and B), whereas no fungal DNA was detected in stem bases of the inoculated plants up to this growth stage in season 2015-16.

From middle October (GS 14) to March (GS 65), mean soil temperatures in $5-\mathrm{cm}$ depth were below $10^{\circ} \mathrm{C}$ in both seasons, and a relative lower average of temperature including 13 days below $0^{\circ} \mathrm{C}$ was found in season $2016-17\left(6.4^{\circ} \mathrm{C}\right)$ compared with season $2015-16$ $\left(7.1^{\circ} \mathrm{C}\right)$, in which the soil temperature consistently remained above $0^{\circ} \mathrm{C}$ (Fig. 2). No further growth of $V$. longisporum in the plants was observed during this period. In the season 2015-16, at the beginning of shoot elongation in early spring (GS 32), V. longisporum only colonized stem bases of the susceptible cultivar, whereas in 2016-17 the stems of both cultivars were infected. Close to harvest, when the soil temperature exceeded $13^{\circ} \mathrm{C}$, growth of $V$. longisporum was drastically enhanced. Furthermore, a particular increase of fungal colonization was found in the susceptible compared with the resistant cultivar $(P<0.05)$ in season $2015-16$. In contrast to the susceptible cultivar Falcon, for which significantly higher amounts of $V$. longisporum DNA were found in stems compared with roots and stem bases of final sampling, stem colonization in the resistant cultivar never exceeded the levels detected in roots and stem bases.

Development of $\boldsymbol{V}$. longisporum in different plant tissues of spring oilseed rape. Samples collected at GS 14, 55, 60 (first flower open), 65, and 80 were analyzed for the detection of colonization and development of $V$. longisporum in the two spring-type oilseed rape genotypes, Visum and OP-DLE 7. The soil temperature was $10.6^{\circ} \mathrm{C}$ in the experimental field when the seeds were sown (Fig. 2). No visible symptoms such as stem striping were observed on both cultivars until ripening stages. 
V. longisporum DNA was not detectable in any tissues of both cultivars until GS 55 (Fig. 3). Similar to winter oilseed rape, levels of $V$. longisporum DNA in both genotypes were equivalent at growth stage GS 60. One week later, a more than 10-fold increase of $V$. longisporum DNA was found at full flowering (GS 65) in roots of both cultivars. Levels of $V$. longisporum DNA in roots at this stage were clearly higher than in winter oilseed rape. No clear difference was found between cultivars. Stem tissues of both cultivars were free of $V$. longisporum until the end of flowering and were only colonized at the beginning of ripening (GS 80). In this growth stage, the highest levels of DNA of $V$. longisporum were found in stem bases, whereas the amounts of $V$. longisporum DNA decreased in roots.
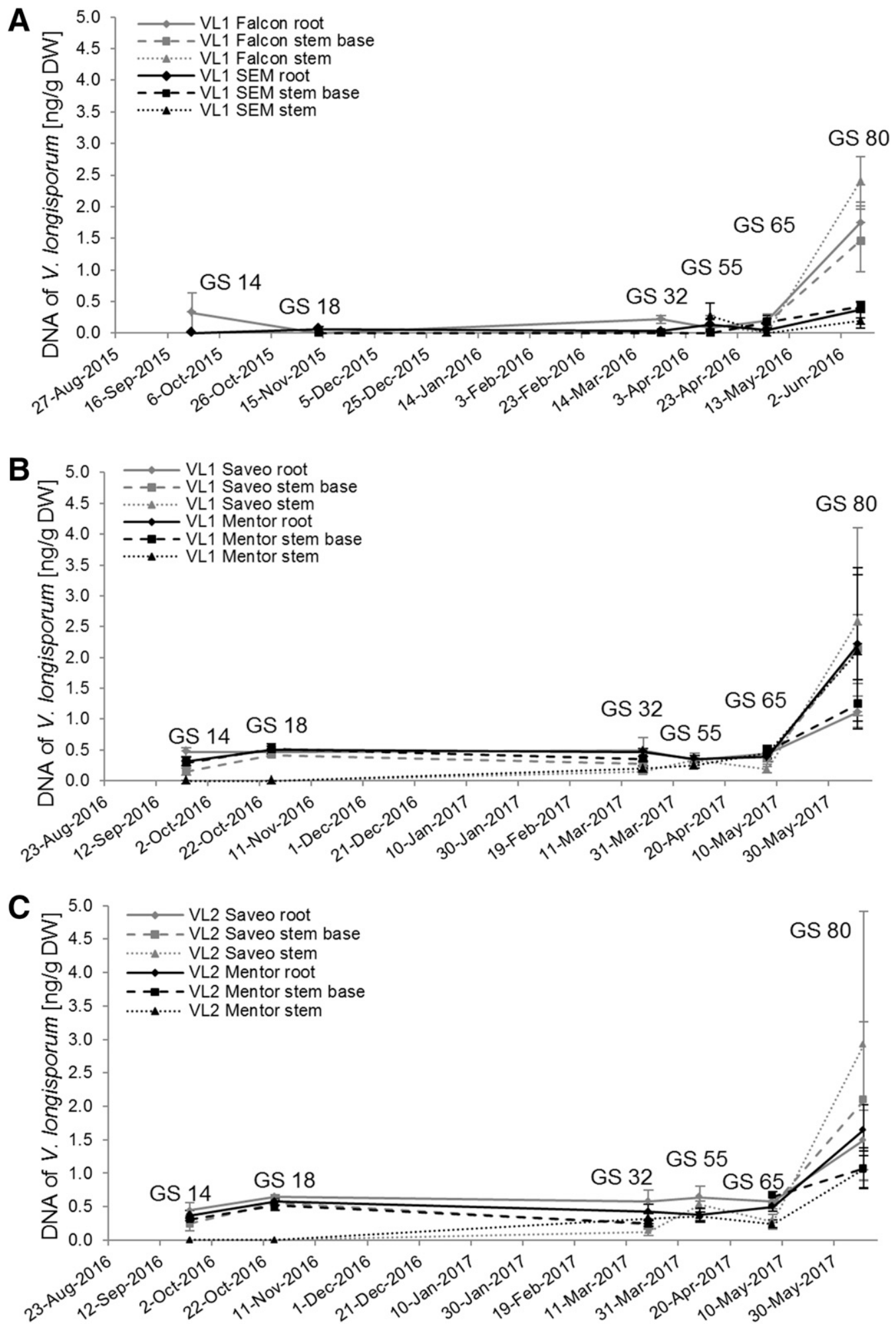

Fig. 1. Colonization of roots, stem bases, and stem tissues of winter oilseed rape (Brassica napus) with Verticillium longisporum from seedling to maturity growth stages in the field experiment 2015-16 (A) and 2016-17 (B, C). Sowing date was 27 August 2015 for the season 2015-16 and 23 August 2016 for the season 2016-17. Data points represent means of four biological replicates consisting of a tissue mixture including five plants. Bars indicate standard errors. Black solid, broken, and dotted lines represent the colonization of $V$. longisporum in roots, stem bases, and stems of resistant cultivar SEM 05-500256 (SEM) or Mentor, respectively. Gray solid, broken, and dotted lines represent the colonization of $V$. Iongisporum in roots, stem bases, and stems of susceptible cultivar Falcon or SY Saveo (Saveo), respectively. GS = growth stage; VL1 = $15 \mathrm{~g} / \mathrm{m}^{2}$ inoculum of $\mathrm{V}$. longisporum; and $\mathrm{VL2}=30 \mathrm{~g} / \mathrm{m}^{2}$ inoculum of $\mathrm{V}$. longisporum; and DW = dry weight. 
Regression analysis of soil temperature and root colonization with $\boldsymbol{V}$. longisporum. Low colonization and slow development of $V$. longisporum were found in both winter and spring oilseed rape during periods with soil temperature below approximately $12^{\circ} \mathrm{C}$ (Figs. 1 and 2). Based on the data of fungal colonization of plants inoculated with $15 \mathrm{~g} / \mathrm{m}^{2}$ inoculum and corresponding soil temperatures from the three field experiments, an exponential model was achieved providing a significant fit of the mean soil temperature in 5-cm depth 7 days before sampling and the colonization of $V$. longisporum in the roots of oilseed rape plants. This data analysis implies an increased colonization of plants with $V$. longisporum with the seasonal increase in soil temperature (Fig. 4).

Disease assessment on stubbles of winter- and spring-type oilseed rape after harvest. In season 2015-16, significantly higher levels of disease incidence and disease severity $(P<0.01)$ were observed both in roots and stems of the susceptible cultivar Falcon $(86 \%, 2.78 \pm 0.07 ; 54 \%, 1.86 \pm 0.07$, respectively) compared with SEM $(59.5 \%, 1.98 \pm 0.07 ; 19 \%, 1.24 \pm 0.04$, respectively).

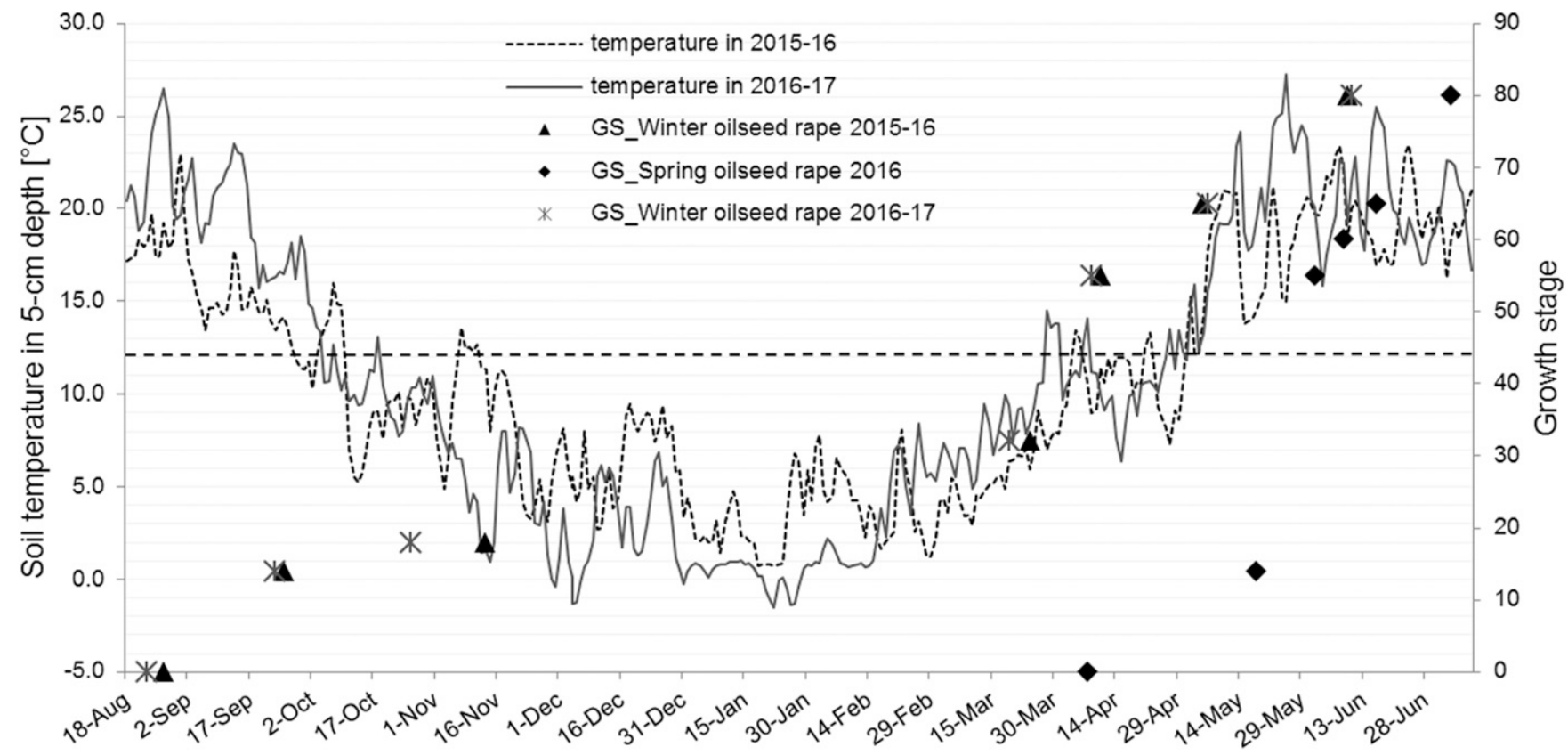

Fig. 2. Soil temperatures in 5-cm depth in the growing seasons 2015-16 and 2016-17 in Göttingen. Triangles, diamonds, and asterisks indicate growth stages (GS) of Brassica napus at the dates of sampling in fields of winter oilseed rape in 2015-16, spring oilseed rape in 2016, and winter oilseed rape in 2016-17, respectively. Data points are daily means of four sensor readings recording the soil temperature at 10-min intervals. GS 0 represents the time of sowing. The dotted line represents $12^{\circ} \mathrm{C}$, which is the threshold temperature for infection of oilseed rape with Verticillium longisporum indicated by data from the climate chamber experiment.
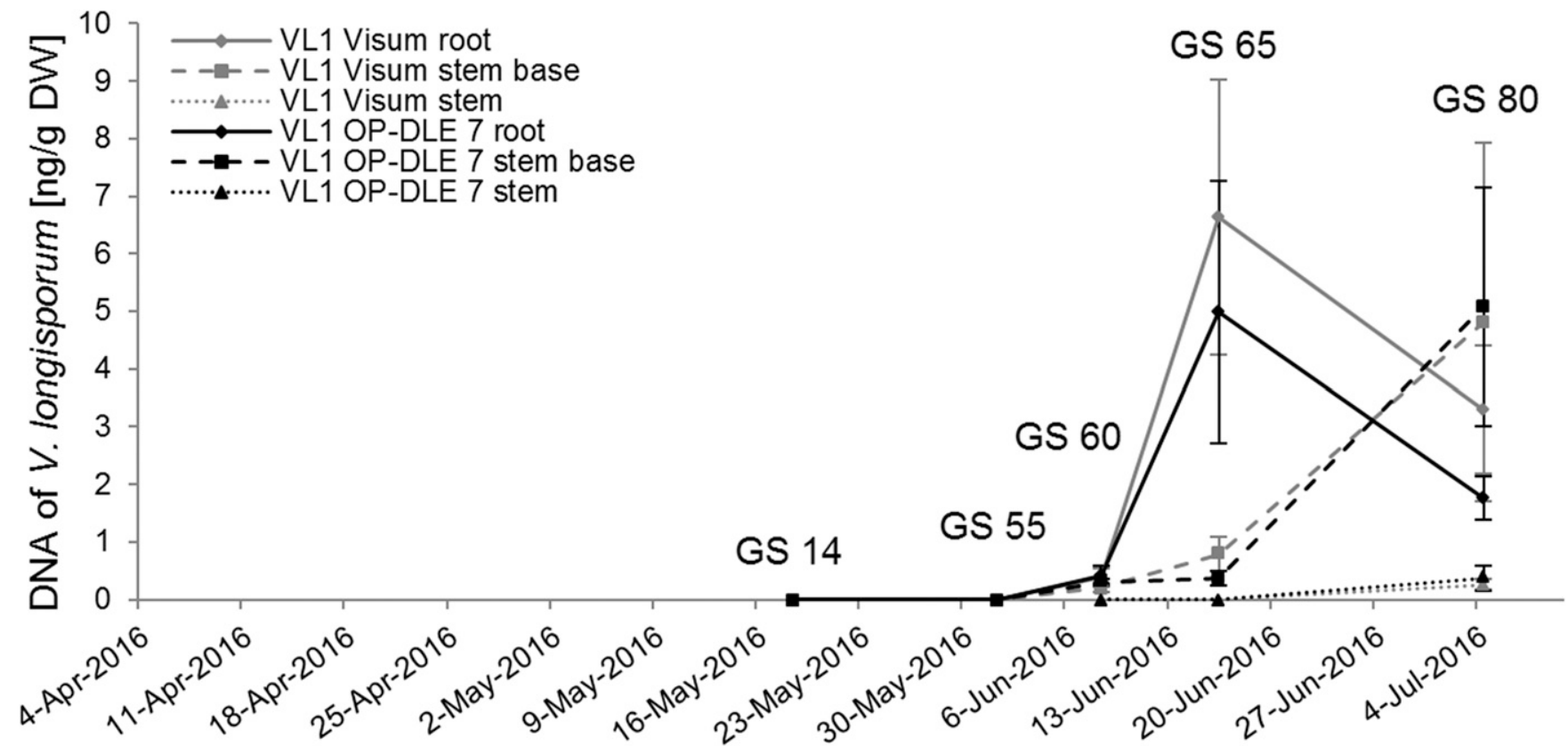

Fig. 3. Colonization of roots, stem bases, and stem tissues of spring oilseed rape (Brassica napus) with Verticillium longisporum from the seedling to maturity growth stages in the field experiment 2016. Plants were sown on 4 April 2016. Data points represent means of four biological replicates consisting of a tissue mixture including five plants. Bars indicate standard errors. Black solid, broken, and dotted lines represent the colonization of V. Iongisporum in roots, stem bases, and stems of the moderately resistant cultivar OP-DLE 7 , respectively. Gray solid, broken, and dotted lines represent the colonization of $V$. longisporum in roots, stem bases, and stems of the moderately susceptible cultivar Visum, respectively. GS = growth stage; and VL1 $=15 \mathrm{~g} / \mathrm{m}^{2}$ inoculum of $\mathrm{V}$. longisporum; and DW = dry weight. 
Generally, disease incidence in season 2016-17 was less than $60 \%$. Similar to the results from real-time PCR, no difference was found between cultivars in 2016-17. In addition, a higher percentage of root samples $(\sim 65 \%)$ from the susceptible cultivar showed advanced development of microsclerotia under the stem epidermis and in the pith tissue in 2015-16 (Fig. 5). In the resistant cultivar of season 2015-16, although about $30 \%$ of root samples were severely infected by $V$. longisporum, distribution of microsclerotia was largely restricted to the root tissue and only rarely $(8 \%)$ reached the stems with low abundance of microsclerotia. However, no significant difference in disease incidence and severity was found among plant parts in 2016-17.

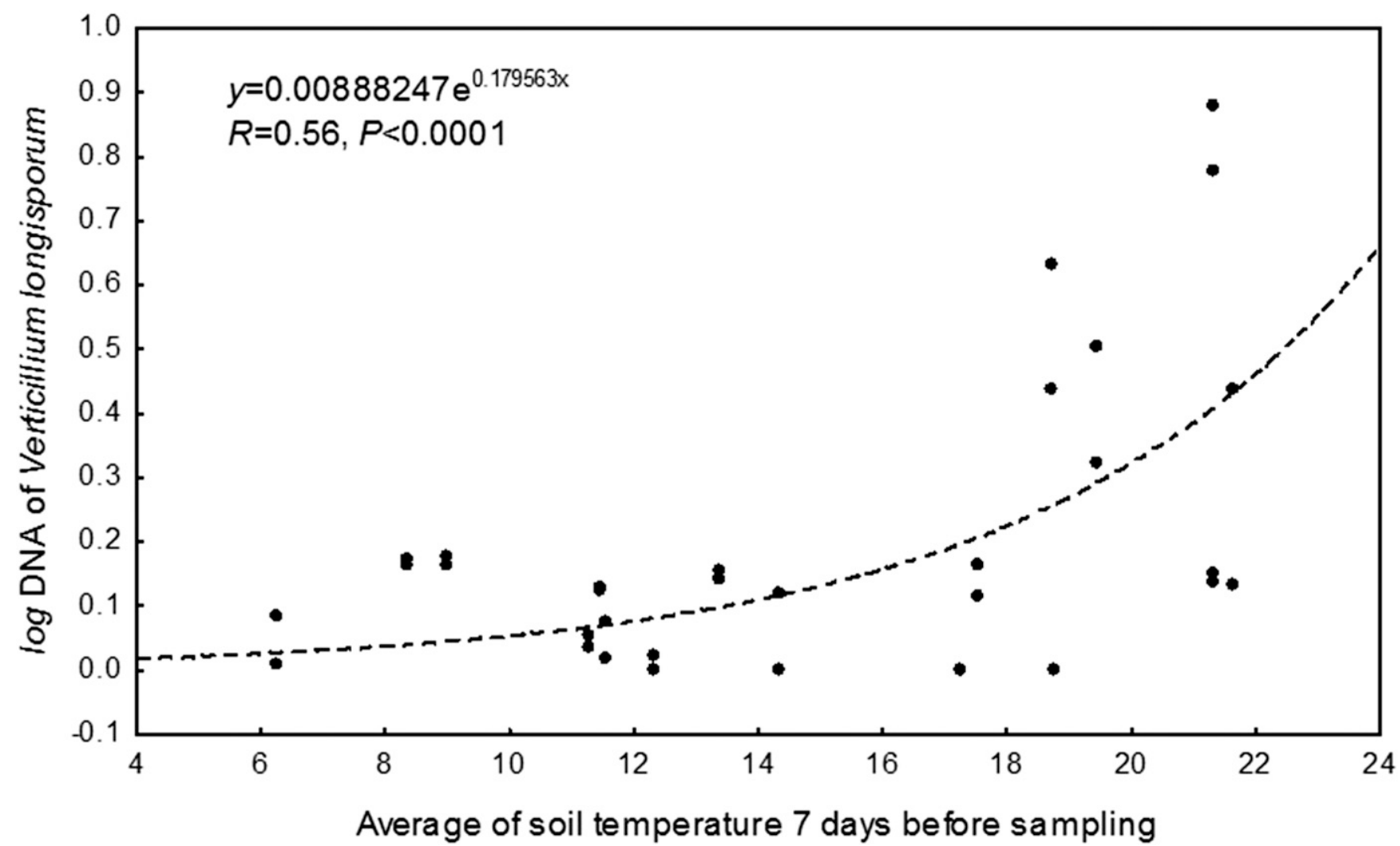

Fig. 4. Regression analysis of the relationship between the average soil temperature in 5-cm depth 7 days before samplings and colonization of oilseed rape roots with Verticillium longisporum (fungal DNA content; inoculated with $15 \mathrm{~g} / \mathrm{m}^{2}$ inoculum). Each data point represents the average of four biological replicates each consisting of five pooled plants. Regression function, coefficient, and significance level are shown on the graph.

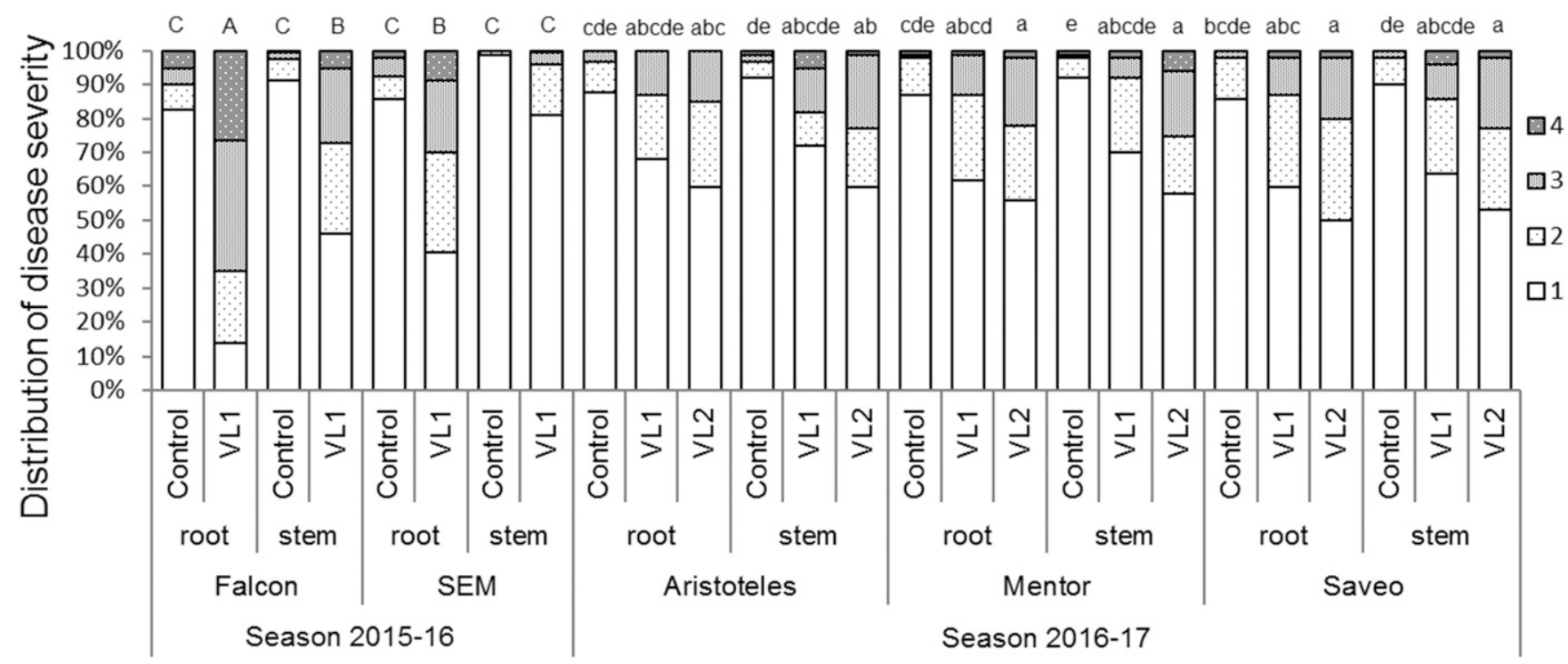

Fig. 5. Disease severity in roots and stems recorded on stubbles harvested from the field trial with winter oilseed rape in the seasons 2015-16 and 2016-17. Disease severity was assessed based on the amount of microsclerotia of Verticillium longisporum visible on the plant samples, in four classes according to Table 1. Different letters indicate significant differences between means of disease severity in season 2015-16 and 2016-17, respectively (Kruskal-Wallis test, $P<0.05$ ). Each data point represents mean disease severity of four biological replicates (50 stubbles/replicate in season $2015-16$ and 25 stubbles/replicate in season 2016-17). VL1 $=15 \mathrm{~g} / \mathrm{m}^{2}$ inoculum of $\mathrm{V}$. longisporum, and VL2 $=30 \mathrm{~g} / \mathrm{m}^{2}$ inoculum of $V$. longisporum. 
In contrast to winter oilseed rape, no significant cultivar effect on disease severity was found on spring oilseed rape. However, slightly more samples from the susceptible cultivar Visum than the less susceptible cultivar OP-DLE 7 were infected by $V$. longisporum and formed microsclerotia in the roots (84 versus $70 \%)$ and stems $(73$ versus $65 \%$ ), respectively. More than $50 \%$ of the samples collected from the more susceptible cultivar showed a high density of microsclerotia in the subepidermal tissues of roots. However, compared with winter oilseed rape, in general, more disease symptoms were found in stem tissues of spring oilseed rape. No differences in disease severity between stems and roots occurred in spring oilseed rape (Fig. 6).

Yield and seed quality of winter oilseed rape. In season 2015-16, a 15\% nonsignificant yield reduction was found in susceptible cultivar Falcon inoculated with $V$. longisporum, whereas yield in the resistant cultivar SEM was not affected. In season 2016-17, a significant yield reduction of $9 \%$ was only found in cultivar Aristoteles (Fig. 7). However, V. longisporum infection had no effect on seed quality (i.e., contents of protein, oil, fatty acids, and glucosinolates) in both susceptible and resistant cultivars (Table 2).

Disease development in the climate chamber. Typical disease symptoms were observed at $35 \mathrm{dpi}$ on the winter oilseed rape cultivar Falcon kept at $18^{\circ} \mathrm{C}$, whereas on Visum (spring oilseed rape), significant effects of inoculation were recorded 1 week later (Fig. 8A). At $42 \mathrm{dpi}$, winter-type cultivars kept at 15 and $18^{\circ} \mathrm{C}$ showed severe symptoms. At $12^{\circ} \mathrm{C}$, very slight symptoms were only detected on Falcon. Compared with Falcon, the spring type Visum showed only moderate disease symptoms at 15 and $18^{\circ} \mathrm{C}$, whereas no clear disease symptoms were observed at $12^{\circ} \mathrm{C}$. Until the end of sampling ( $\left.49 \mathrm{dpi}\right)$, no disease symptoms were recorded on any plant kept at 6 and $9^{\circ} \mathrm{C}$. Similar to the visual disease assessment data, DNA of $V$. longisporum was found in none of the treatments until 28 dpi. However, fungal colonization of plants was detected at 35 dpi in spring type at $18^{\circ} \mathrm{C}$ and in winter type at $15^{\circ} \mathrm{C}$ (Fig. 8B). Until the end of sampling (49 dpi), no fungal DNA was recorded on any plant kept at 6 and $9^{\circ} \mathrm{C}$, whereas at $12^{\circ} \mathrm{C}$ only a very low level of fungal DNA was detected in Falcon. Once $V$. longisporum established in the plant tissue, it displayed a continuous and rapid shoot invasion.

\section{Discussion}

The present study fills a significant knowledge gap by providing - for the first time - data on the temporal course of colonization and development of $V$. longisporum covering the whole growing

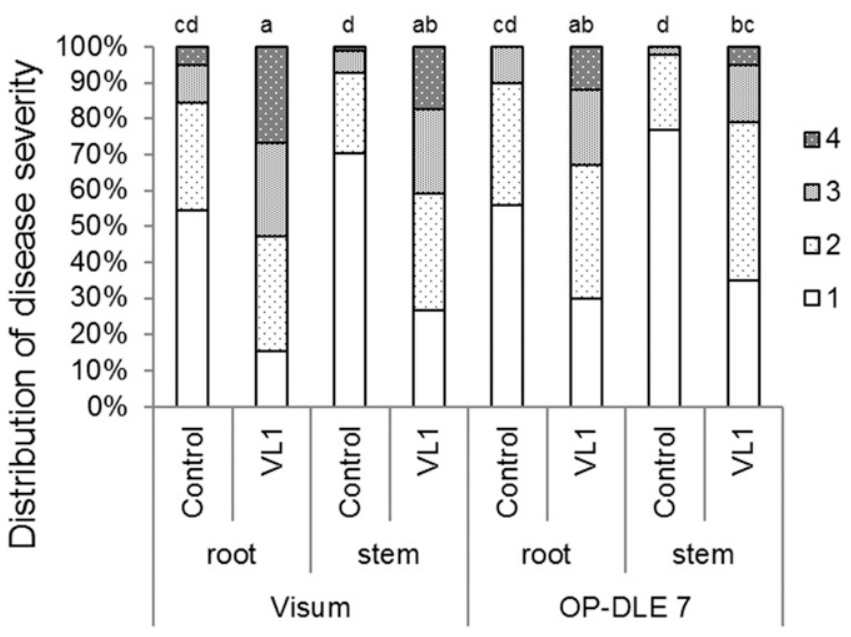

Fig. 6. Disease severity in roots and stems recorded on stubbles harvested from the spring oilseed rape field trial in the season 2016. Disease severity was assessed based on the amount of microsclerotia of Verticillium longisporum visible on the samples in four classes according to Table 1. Different letters indicate significant differences between means of disease severity (Kruskal-Wallis test, $P<0.05$ ). Each data point represents mean disease severity of four biological replicates (25 stubbles/replicate). VL1 $=15 \mathrm{~g} / \mathrm{m}^{2}$ inoculum of $\mathrm{V}$. longisporum. season of B. napus in the field. In contrast to artificial inoculation with $V$. longisporum in greenhouse conditions, where the plants show half-leaf yellowing, vascular discoloration, and stunting (Eynck et al. 2007; Floerl et al. 2008; Zeise and von Tiedemann 2002), such symptoms are seldom or never observed in the field until mature growth stages (GS 80). Symptoms of Verticillium stem striping are the initial signs of infection in the field; however, they can be confused with natural senescence in the late developmental stages or discolorations of the epidermis induced by infection with Leptosphaeria maculans (Phoma stem canker; Fitt et al. 2006).

The occurrence of microsclerotia on mature plants or stubbles is a late symptom that has shown a limited power to reliably quantify disease severity. Hence, real-time PCR analysis has been introduced as a tool for verification and quantification of $V$. longisporum in fieldgrown plants before visual symptoms appear (Knüfer et al. 2017). Likewise, under controlled conditions, real-time PCR analysis of fungal DNA allows for a presymptomatic detection of $V$. longisporum. Similar to the results under greenhouse conditions described in previous studies (Lopisso et al. 2017b; Zhou et al. 2006), V. longisporum was detected in the roots of field-grown winter oilseed rape before winter at the four-leaf stage. However, in the roots of fieldgrown spring oilseed rape, $V$. longisporum was first detectable only at early flowering growth stages. Thus, initial root colonization with $V$. longisporum occurred in spring oilseed rape within 2 months, whereas it took only 1 month in winter oilseed rape. This is related to a sharp contrast in soil temperature at crop emergence. The average soil temperature at the sowing time of winter oilseed rape (August) was 19.2 and $22.0^{\circ} \mathrm{C}$ in 2015 and 2016 , respectively, whereas it was $10.6^{\circ} \mathrm{C}$ at the sowing of spring oilseed rape (April). Earlier in vitro studies showed that the germination rate of $V$. albo-atrum increased with temperature, reaching a maximum at $25^{\circ} \mathrm{C}$ (Mozumder et al. 1970). As confirmed by the climate chamber trial, plant colonization with $V$. longisporum both in winter and spring oilseed rape was entirely inhibited at temperatures below $12^{\circ} \mathrm{C}$. These data suggest that the early colonization of spring oilseed rape with $V$. longisporum was delayed by low soil temperatures during juvenile growth stages, compared with autumn-sown oilseed rape.

These findings are in agreement with previous results from field studies indicating that an earlier sowing time of winter oilseed rape, which provided a longer period of warm weather conditions to the emerging crop, resulted in increased levels of disease incidence, disease severity, and amount of $V$. longisporum colonization of stems (Keunecke 2009). Soil temperature conditions at sowing time may thus explain why early sowing time in winter oilseed rape is considered a risk factor of promoting the disease.

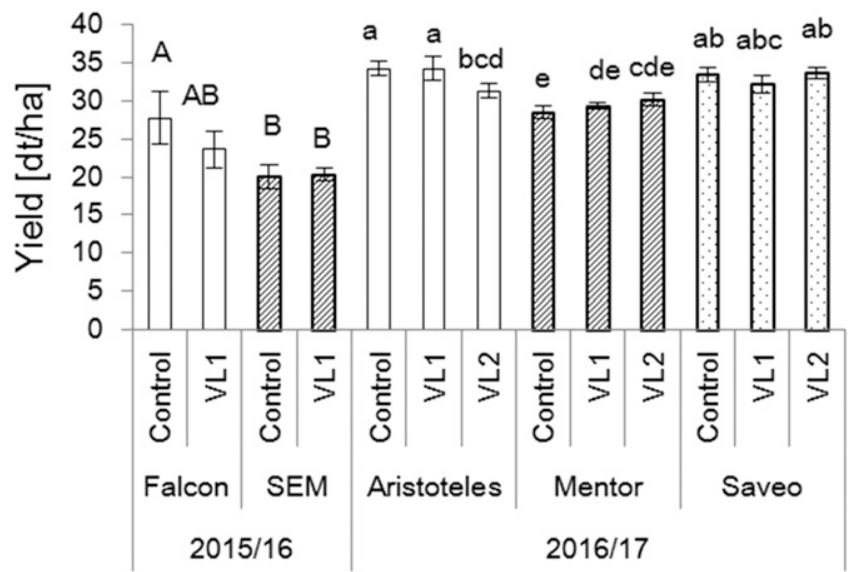

Fig. 7. Oilseed yields from control and Verticillium longisporum-inoculated winter-type Brassica napus in the seasons 2015-16 and 2016-17. Data points are means of four biological replicates. Different letters indicate significant differences between the treatments in season 2015-16 and 2016-17, respectively (LSD test, $P<0.05$ ). Bars indicate standard errors. VL1 $=15 \mathrm{~g} / \mathrm{m}^{2}$ inoculum of $V$. longisporum, and VL2 $=30 \mathrm{~g} / \mathrm{m}^{2}$ inoculum of $\mathrm{V}$. longisporum. 
However, once $V$. longisporum was established in the roots, less time was needed for the pathogen in spring oilseed rape to spread further into the stem base and stem (about 2 months). In autumn 2015, the average soil temperature from sowing winter oilseed rape to eight-leaf stage was $12.4^{\circ} \mathrm{C}$, and no fungal DNA was detected in the stem bases, whereas the average soil temperature during this period in autumn 2016 was $16.4^{\circ} \mathrm{C}$, when $V$. longisporum had already colonized the stem bases of the plants until the same growth stage. However, from the eight-leaf stage in late autumn (mid-November) until full flowering (end of April) the average soil temperature stayed below $12^{\circ} \mathrm{C}$ in both seasons $\left(2015-16,6.3^{\circ} \mathrm{C} ; 2016-17,5.5^{\circ} \mathrm{C}\right)$, which correlated with the delayed systemic spread of $V$. longisporum into the shoots during an extended period of time (about 6 months). This delayed shoot colonization by $V$. longisporum during juvenile stages in the field was in sharp contrast to the colonization of plants inoculated with microsclerotia under controlled conditions, which displayed a continuous and rapid shoot invasion within 35 days after inoculation. Similarly, an increase in outdoor soil temperature of 1.6 or $3.2^{\circ} \mathrm{C}$ resulted in a significant enhancement of $V$. longisporum colonization in winter oilseed rape (Siebold and von Tiedemann 2013). Verticillium dahliae, a close relative of $V$. longisporum, also spread faster into the upper part of pumpkin plants that were kept in warmer temperature conditions $\left(25\right.$ and $30^{\circ} \mathrm{C}$; Rampersad 2010). In the present study, soil temperatures consistently above $15^{\circ} \mathrm{C}$ induced an increased colonization with $V$. longisporum before flowering in spring-type oilseed rape and after flowering in the winter type. This is confirmed by the overall significant regression of soil temperature readings and fungal DNA in roots, as recorded in the field experiments of the present study. In contrast to flowering stages having been shown to be particularly important for $V$. longisporum spread in oilseed rape plants under greenhouse conditions (Zhou et al. 2006), the results of this field study indicate that soil temperature is a crucial factor determining the spread of $V$. longisporum in its host during juvenile growth stages.

Although $V$. longisporum was able to colonize the entire plant in both cultivars and years, in 2015-16 the level of $V$. longisporum DNA in the stem was significantly lower in the resistant genotype. Likewise, fungal spread from roots to stems was more rapid in the susceptible genotype. Interestingly, relatively higher amounts of $V$. longisporum were found in the stem base of the resistant cultivar, which confirms previous findings of a barrier operating in the root-shoot interface, potentially leading to an accumulation of $V$. longisporum in this tissue (Eynck et al. 2009a).

This differential pattern of colonization was reflected by the formation of microsclerotia in roots and stems on stubbles collected postharvest. Although a significantly lower disease score was recorded on stems of the resistant genotype, a considerable amount of fungal resting structures was found on the roots, implying that
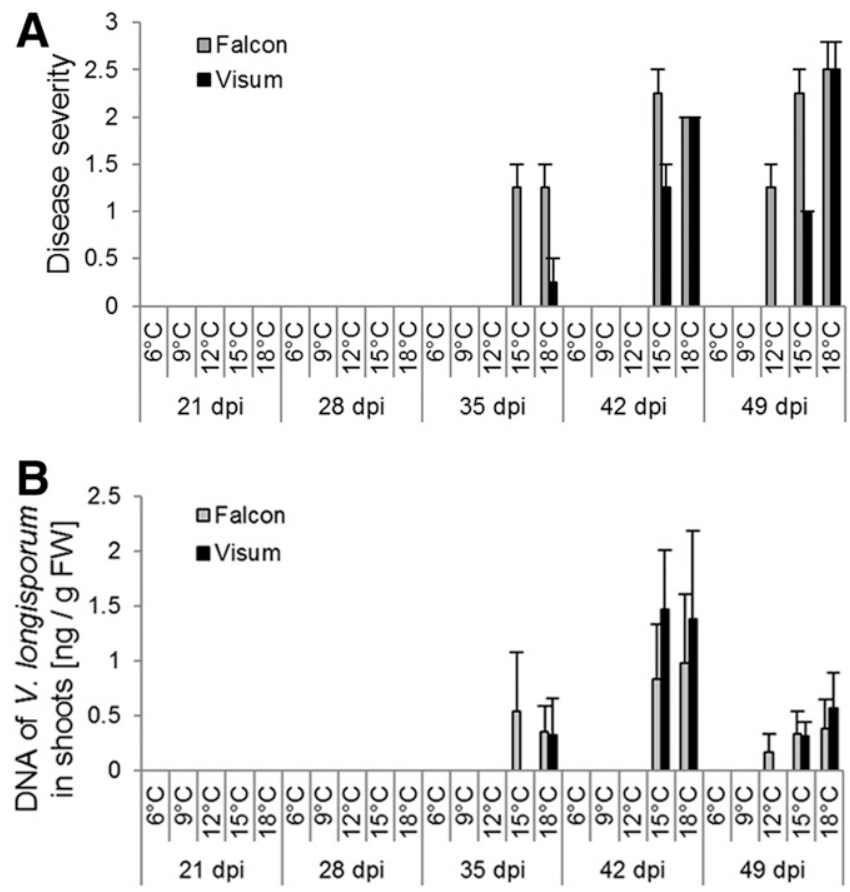

Fig. 8. Progress of net disease severity (A) and fungal colonization (B) in winter- and spring-type oilseed rape inoculated with microsclerotia of $V$. longisporum and grown in the climate chamber at different temperature regimes. Biomass of $V$. longisporum is represented by the amount of fungal DNA in shoots $(B)$. No DNA of $V$. longisporum was detected in control plants. Data points represent means of four biological replicates consisting of two merged plant samples. Bars indicate standard errors. No significant differences were found among treatments (Kruskal-Wallis test, $P<0.05$ ). $\mathrm{FW}=$ fresh weight.

Table 2. Seed quality of control and Verticillium longisporum-inoculated winter oilseed rape in the seasons 2015-16 and 2016-17

\begin{tabular}{|c|c|c|c|c|c|c|}
\hline \multirow[b]{2}{*}{ Treatment } & \multirow[b]{2}{*}{ Protein (\%) } & \multirow[b]{2}{*}{ Oil $(\%)$} & \multicolumn{3}{|c|}{ Fatty acids } & \multirow{2}{*}{$\begin{array}{r}\text { Glucosinolates } \\
(\mu \mathrm{mol} / \mathrm{g} \text { DW })\end{array}$} \\
\hline & & & Oleic (\% in oil) & Linolenic (\% in oil) & Erucic (\% in oil) & \\
\hline \multicolumn{7}{|c|}{ Season 2015-16 } \\
\hline \multicolumn{7}{|c|}{ Falcon } \\
\hline Control & $18.3 \pm 0.3 \mathrm{~B}$ & $42.1 \pm 0.4 \mathrm{~B}$ & $60.33 \pm 0.1 \mathrm{~B}$ & $10.54 \pm 0.1 \mathrm{~A}$ & $<2 \mathrm{~B}$ & $10.8 \pm 0.3 \mathrm{~A}$ \\
\hline VL1 & $18.0 \pm 0.1 \mathrm{AB}$ & $42.4 \pm 0.2 \mathrm{~B}$ & $60.00 \pm 0.1 \mathrm{~B}$ & $10.60 \pm 0.1 \mathrm{~A}$ & $<2 \mathrm{AB}$ & $11.0 \pm 0.3 \mathrm{~A}$ \\
\hline \multicolumn{7}{|c|}{ SEM 05-500256 } \\
\hline Control & $18.6 \pm 0.0 \mathrm{~A}$ & $43.2 \pm 0.1 \mathrm{~A}$ & $63.0 \pm 0.2 \mathrm{~A}$ & $10.32 \pm 0.0 \mathrm{~B}$ & $<2 \mathrm{~B}$ & $9.3 \pm 0.2 \mathrm{~B}$ \\
\hline VL1 & $18.7 \pm 0.0 \mathrm{~A}$ & $43.3 \pm 0.1 \mathrm{~A}$ & $63.2 \pm 0.1 \mathrm{~A}$ & $10.35 \pm 0.0 \mathrm{~B}$ & $<2 \mathrm{AB}$ & $9.2 \pm 0.3 \mathrm{~B}$ \\
\hline \multicolumn{7}{|c|}{ Season 2016-17 } \\
\hline \multicolumn{7}{|l|}{ Aristoteles } \\
\hline Control & $18.5 \pm 0.1 \mathrm{ab}$ & $41.8 \pm 0.2 \mathrm{bc}$ & $62.7 \pm 0.2 \mathrm{c}$ & $9.44 \pm 0.1 \mathrm{bc}$ & $<2 a b$ & $11.0 \pm 0.6 \mathrm{ab}$ \\
\hline VL1 & $18.4 \pm 0.2 \mathrm{ab}$ & $41.9 \pm 0.3 \mathrm{abc}$ & $63.2 \pm 0.2 \mathrm{ab}$ & $9.51 \pm 0.1 \mathrm{abc}$ & $<2 \mathrm{bc}$ & $11.1 \pm 0.6 \mathrm{ab}$ \\
\hline VL2 & $18.7 \pm 0.2 \mathrm{a}$ & $41.3 \pm 0.2 \mathrm{c}$ & $62.8 \pm 0.1 \mathrm{bc}$ & $9.47 \pm 0.0 \mathrm{abc}$ & $<2 \mathrm{bc}$ & $11.0 \pm 0.5 \mathrm{ab}$ \\
\hline \multicolumn{7}{|l|}{ Mentor } \\
\hline Control & $18.7 \pm 0.1 \mathrm{ab}$ & $42.2 \pm 0.1 \mathrm{ab}$ & $63.4 \pm 0.2 \mathrm{a}$ & $9.44 \pm 0.1 \mathrm{bc}$ & $<2 \mathrm{ab}$ & $11.0 \pm 0.4 \mathrm{ab}$ \\
\hline VL1 & $18.5 \pm 0.1 \mathrm{ab}$ & $42.4 \pm 0.1 \mathrm{a}$ & $63.0 \pm 0.2 \mathrm{abc}$ & $9.34 \pm 0.0 \mathrm{bc}$ & $<2 \mathrm{abc}$ & $10.3 \pm 0.4 \mathrm{~b}$ \\
\hline VL2 & $18.5 \pm 0.2 \mathrm{ab}$ & $42.2 \pm 0.2 \mathrm{ab}$ & $63.0 \pm 0.1 \mathrm{abc}$ & $9.30 \pm 0.1 \mathrm{c}$ & $<2 \mathrm{c}$ & $11.6 \pm 0.5 \mathrm{ab}$ \\
\hline \multicolumn{7}{|l|}{ Saveo } \\
\hline Control & $18.6 \pm 0.1 \mathrm{ab}$ & $41.5 \pm 0.3 \mathrm{c}$ & $62.7 \pm 0.3 b c$ & $9.49 \pm 0.1 \mathrm{abc}$ & $<2 \mathrm{ab}$ & $11.8 \pm 0.4 \mathrm{a}$ \\
\hline VL1 & $18.7 \pm 0.2 \mathrm{a}$ & $41.5 \pm 0.2 \mathrm{c}$ & $62.6 \pm 0.1 \mathrm{c}$ & $9.67 \pm 0.1 \mathrm{a}$ & $<2 \mathrm{a}$ & $11.2 \pm 0.5 \mathrm{ab}$ \\
\hline VL2 & $18.3 \pm 0.0 \mathrm{~b}$ & $41.9 \pm 0.2 \mathrm{abc}$ & $62.6 \pm 0.2 \mathrm{c}$ & $9.55 \pm 0.1 \mathrm{ab}$ & $<2 a b c$ & $11.2 \pm 0.4 \mathrm{ab}$ \\
\hline
\end{tabular}

${ }^{\mathrm{z}}$ Each value represents the mean of four biological replicates \pm standard errors. Different letters indicate significant differences between treatments for each parameter in seasons 2015-16 and 2016-17, respectively (LSD test, $P<0.05$ ). VL1 $=15 \mathrm{~g} / \mathrm{m}^{2}$ inoculum of V. longisporum; VL2 $=30 \mathrm{~g} / \mathrm{m}^{2}$ inoculum of V. longisporum; and DW = dry weight. 
partial resistance in oilseed rape cannot entirely cut the disease cycle of $V$. longisporum. However, in contrast to the real-time PCR data at GS 80, roots of susceptible winter oilseed rape at harvest were more severely affected by microsclerotia formation than stems; such discrepancies indicate limitations in visual postharvest disease scoring (Knüfer et al. 2017). The lack of significant differences in stubble infestation between the two spring-type genotypes corresponded with the similar patterns of colonization during the growth season.

Previous studies reported yield reductions through $V$. longisporum on single plants ranging from 20 to $80 \%$ in the greenhouse and assumed a potential overall yield loss in the field ranging from 10 to $50 \%$ if $60 \%$ of plants had shown severe disease symptoms (Dunker et al. 2008; Paul 2003). These findings were largely confirmed with the data from season 2015-16, in which Falcon at $65 \%$ disease incidence recorded postharvest on stubbles displayed a total average yield loss of $15 \%$ in the field, which however was statistically not significant. In all other cultivars and years with less than 55\% disease incidence, damage of single plants was obviously compensated by the whole plant stand, avoiding an overall yield reduction and confirming previous studies with oilseed rape in the field (Dunker et al. 2008; Tatchell 1983).

All data on yield effects of $V$. longisporum available so far from the field generally indicate a relatively low damage level induced by this pathogen. In addition, a recent study found strong inconsistencies in yield responses to $V$. longisporum infection in oilseed rape grown in different years and locations (Depotter et al. 2019). This general observation may be now explainable by the findings of the present study, which indicates a strong delay in colonization of plants in the field owing to the environmental conditions, particularly low soil temperatures. The extended period of extremely low growth rates of the fungus in the plant base associated with the constriction to single vascular strings and a lack of wilt stress, as described previously (Eynck et al. 2007; Lopisso et al. 2017b), may be the reason for the moderate level of yield damage induced by $V$. longisporum in fieldgrown winter oilseed rape. Likewise, major seed quality parameters such as oil content and its composition of proteins, fatty acids, and glucosinolates were unaffected by $V$. longisporum, confirming previous reports (Dunker et al. 2008). This also corresponds to a recent study indicating that $V$. longisporum is not likely to be transmitted to seeds in field-grown winter oilseed rape owing to the delayed systemic colonization (Zheng et al. 2019).

The present study focused on winter oilseed rape, because it is by far the dominant type of oilseed crop cultivation in Europe. Spring-type oilseed rape was used for comparison of the colonization patterns and in order to illustrate the role of environmental conditions as compared with crop growth stages. The present study, however, also indicates that, owing to a different coincidence of plant growth stages with environmental conditions, the overall colonization is faster and stronger in the spring-type crop. This may have serious implications for the role of $V$. longisporum in spring-sown oilseed rape, in which the faster colonization may likely enhance the risk of seed contamination (Zheng et al. 2019) and increase the potential yield damage.

\section{Author Contributions}

X.Z., A.W., B.K., and A.v.T. designed and performed the research. X.Z., A.W., A.P., L.K., and A.B.E. performed the field work and visual assessment. A.P. L.K., and A.B.E. performed the molecular work. X.Z., A.P., L.K., and A.B.E analyzed the data. All authors discussed results and implications. X.Z. and A.v.T. wrote the manuscript. All authors have read and approved the final manuscript.

\section{Acknowledgments}

The authors thank Evelin Vorbeck, Dagmar Tacke, and Hubertus Reintke for their excellent technical assistance. The support by Christian Möller, Division of Plant Breeding, University of Göttingen, in the seed quality analysis is gratefully acknowledged.

\section{Literature Cited}

Brandfass, C., and Karlovsky, P. 2008. Upscaled CTAB-based DNA extraction and real-time PCR assays for Fusarium culmorum and F. graminearum DNA in plant material with reduced sampling error. Int. J. Mol. 9:2306-2321.
Debode, J., van Poucke, K., França, S. C., Maes, M., Höfte, M., and Heungens, K. 2011. Detection of multiple Verticillium species in soil using density flotation and real-time polymerase chain reaction. Plant Dis. 95:1571-1580.

Depotter, J. R. L., Deketelaere, S., Inderbitzin, P., von Tiedemann, A., Höfte, M., Subbarao, K. V., Wood, T. A., and Thomma, B. P. H. J. 2016. Verticillium longisporum, the invisible threat to oilseed rape and other brassicaceous plant hosts. Mol. Plant Pathol. 17:1004-1016.

Depotter, J. R. L., Thomma, B. P. H. J., and Wood, T. A. 2019. Measuring the impact of Verticillium longisporum on oilseed rape (Brassica napus) yield in field trials in the United Kingdom. Eur. J. Plant Pathol. 153: 321-326.

Dunker, S., Keunecke, H., Steinbach, P., and von Tiedemann, A. 2008. Impact of Verticillium longisporum on yield and morphology of winter oilseed rape (Brassica napus) in relation to systemic spread in the plant. J. Phytopathol. 156:698-707.

Eynck, C., Koopmann, B., Grunewaldt-Stoecker, G., Karlovsky, P., and von Tiedemann, A. 2007. Differential interactions of Verticillium longisporum and V. dahliae with Brassica napus detected with molecular and histological techniques. Eur. J. Plant Pathol. 118:259-274.

Eynck, C., Koopmann, B., Karlovsky, P., and von Tiedemann, A. 2009a. Internal resistance in winter oilseed rape inhibits systemic spread of the vascular pathogen Verticillium longisporum. Phytopathology 99:802-811.

Eynck, C., Koopmann, B., and von Tiedemann, A. 2009b. Identification of Brassica accessions with enhanced resistance to Verticillium longisporum under controlled and field conditions. J. Plant Dis. Prot. 116:63-72.

Fitt, B. D. L., Brun, H., Barbetti, M. J., and Rimmer, S. R. 2006. World-wide importance of Phoma stem canker (Leptosphaeria maculans and $L$. biglobosa) on oilseed rape (Brassica napus). Eur. J. Plant Pathol. 114:3-15.

Floerl, S., Druebert, C., Majcherczyk, A., Karlovsky, P., Kües, U., and Polle, A. 2008. Defence reactions in the apoplastic proteome of oilseed rape (Brassica napus var. napus) attenuate Verticillium longisporum growth but not disease symptoms. BMC Plant Biol. 8:129.

Friedt, W., and Snowdon, R. 2009. Oilseed rape. Pages 91-126 in: Handbook of Plant Breeding. J. Vollmann and I. Rajcan, eds. Springer, London, U.K.

Gladders, P., Richie, F., Babara, D., Clarkson, J., Chantry, T., Taylor, M., and Turner, J. 2013. Importance and Management of Verticillium Wilt in Winter Oilseed Rape. HGCA Project Report No. 512. Project RD-20093618. HGCA, Agriculture and Horticulture Development Board, Kenilworth, U.K.

Heale, J. B., and Karapapa, V. K. 1999. The Verticillium threat to Canada's major oilseed crop: Canola. Can. J. Plant Pathol. 21:1-7.

Karapapa, V. K., Bainbridge, B. W., and Heale, J. B. 1997. Morphological and molecular characterization of Verticillium longisporum comb, nov., pathogenic to oilseed rape. Mycol. Res. 101:1281-1294.

Keunecke, H. 2009. Impact of cabbage root fly on infections and damage potential of Verticillium longisporum and Phoma lingam in oilseed rape. $\mathrm{Ph} . \mathrm{D}$. dissertation. Georg August University, Göttingen, Germany.

Knüfer, J., Lopisso, D. T., Koopmann, B., Karlovsky, P., and von Tiedemann, A. 2017. Assessment of latent infection with Verticillium longisporum in fieldgrown oilseed rape by qPCR. Eur. J. Plant Pathol. 147:819-831.

Kroeker, G. 1970. Vissnesjuka på raps och rybs i Skåne orsakad av Verticillium. Sven. Frotidn. 19:10-13.

Lancashire, P. D., Bleiholder, H., van den Boom, T., Langelüddeke, P., Stauss, R., Weber, E., and Witzenberger, A. 1991. A uniform decimal code for growth stages of crops and weeds. Ann. Appl. Biol. 119:561-601.

Lopisso, D. T., Knüfer, J., Koopmann, B., and von Tiedemann, A. 2017a. Growth of Verticillium longisporum in xylem sap of Brassica napus is independent from cultivar resistance but promoted by plant aging. Phytopathology 107: 1047-1054.

Lopisso, D. T., Knüfer, J., Koopmann, B., and von Tiedemann, A. 2017b. The vascular pathogen Verticillium longisporum does not affect water relations and plant responses to drought stress of its host, Brassica napus. Phytopathology 107:444-454.

Mozumder, B. K., Caroselli, N. E., and Albert, L. S. 1970. Influence of water activity, temperature, and their interaction on germination of Verticillium albo-atrum conidia. Plant Physiol. 46:347-349.

Paul, V. H. 2003. Raps: Krankheiten, Schädlinge, Schadpflanzen. Mann, Gelsenkirchen-Buer, Germany.

Ralhan, A., Schöttle, S., Thurow, C., Iven, T., Feussner, I., Polle, A., and Gatz, C. 2012. The vascular pathogen Verticillium longisporum requires a jasmonic acid-independent COI1 function in roots to elicit disease symptoms in Arabidopsis shoots. Plant Physiol. 159:1192-1203.

Rampersad, S. N. 2010. A study of environmental factors that affect survival of pumpkin isolates of Verticillium dahliae. HortScience 45:1211-1217.

Rygulla, W., Snowdon, R. J., Friedt, W., Happstadius, I., Cheung, W. Y., and Chen, D. 2008. Identification of quantitative trait loci for resistance against Verticillium longisporum in oilseed rape (Brassica napus). Phytopathology 98:215-221.

Siebold, M., and von Tiedemann, A. 2013. Effects of experimental warming on fungal disease progress in oilseed rape. Glob. Change Biol. 19:1736-1747.

Tatchell, G. M. 1983. Compensation in spring-sown oil-seed rape (Brassica napus L.) plants in response to injury to their flower buds and pods. J. Agric. Sci. 101: 565-573. 
Tyvaert, L., França, S. C., Debode, J., and Höfte, M. 2014. The endophyte Verticillium Vt305 protects cauliflower against Verticillium wilt. J. Appl. Microbiol. 116:1563-1571.

U.S. Department of Agriculture (USDA). 2018. Oilseeds: World Markets and Trade. Accessed 22 June 2018. https://apps.fas.usda.gov/psdonline/circulars/ oilseeds.pdf.

Weber, E., and Bleiholder, H. 1990. Erläuterungen zu den BBCH-Dezimal-Codes für die Entwicklungsstadien von Mais, Raps, Faba-Bohne, Sonnenblume und Erbse - mit Abbildungen. Gesunde Pflanzen 42:308-321.

Zając, T., Klimek-Kopyra, A., Oleksy, A., Lorenc-Kozik, A., and Ratajczak, K. 2016. Analysis of yield and plant traits of oilseed rape (Brassica napus L.) cultivated in temperate region in light of the possibilities of sowing in arid areas. Acta Agrobot. 69:1696.

Zeise, K., and von Tiedemann, A. 2002. Host specialization among vegetative compatibility groups of Verticillium dahliae in relation to Verticillium longisporum. J. Phytopathol. 150:112-119.

Zheng, X., Loppisso, D. T., Eseola, A. B., Koopmann, B., and von Tiedemann, A 2019. Potential for seed transmission of Verticillium longisporum in oilseed rape (Brassica napus). Plant Dis. doi: 10.1094/PDIS-11-18-2024-RE.

Zhou, L., Hu, Q., Johansson, A., and Dixelius, C. 2006. Verticillium longisporum and $V$. dahliae: Infection and disease in Brassica napus. Plant Pathol. 55: $137-144$. 